\title{
PENGOLAHAN SAMPAH SAYURAN MENJADI KOMPOS DENGAN METODE TAKAKURA
}

\author{
Processing Vegetable Waste Into Compost With Takakura Method
}

\author{
Adella Atika Larasati ${ }^{1 *}$, Septa Indra Puspikawati ${ }^{2}$ \\ ${ }^{12}$ Departemen Kesehatan Lingkungan, Program Studi Kesehatan Masyarakat, Fakultas Kesehatan \\ Masyarakat PSDKU Universitas Airlangga, Banyuwangi \\ *email: adella.atika.larasati-2016@fkm.unair.ac.id
}

\begin{abstract}
The increasing household activity is increasing also the amount of vegetables waste produced will cause a pile of decomposed waste, so that proper waste management is needed. The processing of waste done by the Community is still conventional that takes a long time so needed an innovation by re-utilizing garbage into compost with the method Takakura. This research aims to determine the comparison of physical parameters (temperature, $\mathrm{pH}$, humidity, smell, color and texture) between the control group and the treatment group in making compost with Takakura method. This research method utilizes an experimental semi-quasi design with a control group and a treatment group conducted in the PSDKU Environmental Health Laboratory of Airlangga University in Banyuwangi during February-April 2019. The results showed that the parameters of physical quality compost vegetable waste without the addition of bioaktivator is the temperature of $29^{\circ} \mathrm{C}, \mathrm{pH} 6.8$, humidity $45 \%$, colored blackish, smelling soil and texture like soil. While the parameters of physical quality compost vegetable garbage with the addition of Bioaktivator EM4 is $30^{\circ} \mathrm{C}$ temperature, $\mathrm{pH} 6.8$, humidity 50\%, colored blackish, smelling soil and texture like soil. Conclusion of making compost with vegetable garbage method Takakura obtained the temperature parameter of the treatment group higher than the control group, the $\mathrm{pH}$ of both groups, the humidity of the treatment group is higher or moist than With the control group as well as the color, smell and texture of both groups in accordance with the guidelines SNI 19-7030-2004.
\end{abstract}

Keywords: compost, EM4, vegetable waste, Takakura

\begin{abstract}
Abstrak
Semakin bertambahnya aktivitas rumah tangga yang dilakukan semakin meningkat pula sampah sayuran yang dihasilkan akan menyebabkan tumpukan sampah yang membusuk sehingga diperlukan adanya pengolahan sampah yang benar. Pengolahan sampah yang dilakukan oleh masyarakat masih secara konvensional yang memerlukan waktu yang lama sehingga diperlukan suatu inovasi dengan cara memanfaatkan kembali sampah menjadi kompos dengan metode takakura. Penelitian ini bertujuan untuk mengetahui perbandingan parameter fisik (suhu, $\mathrm{pH}$, kelembapan, bau, warna dan tekstur) antara kelompok kontrol dan kelompok perlakuan pada pembuatan kompos dengan metode takakura. Metode penelitian ini menggunakan desain semi quasi eksperimental dengan kelompok kontrol dan kelompok perlakuan yang dilakukan di Laboratorium Kesehatan Lingkungan PSDKU Universitas Airlangga di Banyuwangi selama bulan Februari-April 2019. Hasil penelitian menunjukkan bahwa parameter kualitas fisik pada kompos sampah sayuran tanpa penambahan bioaktivator adalah suhu $29^{\circ} \mathrm{C}, \mathrm{pH} 6,8$, kelembapan $45 \%$, berwarna kehitaman, berbau tanah dan tekstur seperti tanah. Sedangkan parameter kualitas fisik pada kompos sampah sayuran dengan penambahan bioaktivator EM4 adalah suhu $30^{\circ} \mathrm{C}, \mathrm{pH} 6,8$, kelembapan $50 \%$, berwarna kehitaman, berbau tanah dan tekstur seperti tanah. Kesimpulan pembuatan kompos dengan sampah sayuran metode takakura didapatkan parameter suhu kelompok perlakuan lebih tinggi dibanding dengan kelompok kontrol, $\mathrm{pH}$ kedua kelompok sama, kelembapan kelompok perlakuan lebih tinggi atau lembab dibandingkan dengan kelompok kontrol serta warna, bau dan tekstur kedua kelompok sama sesuai denga pedoman SNI 19-7030-2004.
\end{abstract}

Kata kunci: EM4, kompos, sampah sayuran, takakura 


\section{PENDAHULUAN}

Lingkungan sangat penting dalam keberlangsungan makhluk hidup, terutama manusia. Salah satu permasalahan lingkungan yang masih menjadi perhatian serius yaitu sampah. Sampah merupakan sesuatu yang dibuang dan tidak terpakai yang berasal dari kegiatan yang dilhasilkan oleh manusia setiap harinya secara terus menerus dan berbentuk padat. Sampah menurut jenisnya dibagi menjadi dua yaitu sampa organik dan sampah anorganik. Sampah organik adalah sampah yang mudah diuraikan yang berasal dari sisa makanan, daundaunan, buah-buahan, sisa kegiatan dapur dan sisa sayuran. Sedangkan sampah anorganik adalah sampah yang tidak mudah diuraikan yang berasal dari plastik, kertas, logam (Nisandi, 2007).

Berdasarkan data Kabupaten Banyuwangi tahun 2011 tercatat pertumbuhan volume sampah sebesar $218 \mathrm{~m}^{3}$ per hari dengan jumlah sampah per tahun sebesar 1.089.254.600 ton atau dengan kata lain jumlah sampah di Kabupaten Banyuwangi meningkat rata-ratanya sebesar $11,53 \%$ per tahun dengan persentase sampah di Kecamatan Banyuwangi sampah organik sebesar $81,59 \%$, sampah plastik sebesar $11 \%$, sampah kertas sebesar 5,69\%, sampah tekstil sebesar $1,66 \%$ dan sampah kaca sebesar 0,39\% (Perda Banyuwangi, 2013). Sumber sampah dapat bervariasi diantaranya berasal dari kegiatan rumah tangga, pasar, industri, warung, kantor, bangunan umum dan jalan.

Semakin bertambahnya aktivitas rumah tangga yang dilakukan semakin meningkat pula sampah sayuran yang dihasilkan akan menyebabkan tumpukan sampah yang membusuk sehingga menimbulkan bau yang tidak sedap, mencemari lingkungan dan menjadi sumber penyakit yang berdampak pada gangguan terhadap kesehatan masyarakat (Ekawandani, 2018). Penumpukan sampah terutama sampah sisa sayuran perlu dilakukan pengolahan sampah yang baik dan benar. Pengolahan sampah yang dilakukan oleh masyarakat masih secara konvensional yang memerlukan waktu yang lama sehingga dapat diperlukan suatu inovasi dengan cara mengolah kembali sampah secara sederhana dengan memanfaatkan kembali sampah menjadi kompos. Kompos merupakan pupuk yang dibuat dari bahan-bahan organik seperti sampah dapur rumah tangga, daun-daunan, kotoran lain, rumput yang dapat meningkatkan kesuburan tanah. Cara pengolahan sampah organik menjadi kompos, salah satunya dengan metode keranjang Takakura. Kelebihan dari metode takakura yaitu praktis, efisien dan mudah diterapkan menjadi pupuk yang bernilai ekonomis yang dirancang untuk mengolah sampah organik dengan sangat baik pada skala rumah tangga (Kurniati, 2013).

Berdasarkan penelitian Zuhrufah, dkk (2015), pembuatan pupuk organik dengan metode takakura menggunakan penambahan bioaktivator EM4 dan tanpa penambahan bioaktivator EM4. Pada pembuatan pupuk organik takakura dengan penambahan biaktivator EM4 didapatkan hasil pupuk berwarna sangat hitam menyerupai tanah, berbau tanah dan memiliki tekstur remah serta halus. Sedangkan pupuk organik takakura tanpa penambahan bioaktivator EM4 didapatkan hasil berwarna lebih coklat, berbau seperti tanah dan memiliki tekstur remah namun lebih kasar (Zuhrufa et. al, 2015).

Berdasarkan SNI 19-7030-2004 tentang spesifikasi kompos dari sampah organik, menjelaskan bahwa persyaratan parameter yang telah ditetapkan adalah kompos yang sudah jadi atau matang harus memenuhi suhu kompos lebih besar dari $22^{\circ} \mathrm{C}, \mathrm{pH}$ kompos sebesar berkisar antaa 6,80 - 7,40, kelembapan maksimal sebesar 50\%, kompos yang dihasilkan berbau tanah, warna kompos menjadi kehitaman dan memiliki tekstur seperti tanah (BSN, 2004).

Berdasarkan uraian di atas, maka perlu dilakukan penelitian tentang "Pengolahan Sampah Sayuran menjadi Kompos dengan Metode Takakura". Tujuan dalam penelitian ini adalah untuk mengetahui perbandingan parameter fisik seperti suhu, $\mathrm{pH}$, kelembapan, bau, warna dan tekstur kompos pada pembuatan kompos metode takakura dengan bahan baku sampah sayuran sesuai dengan pedoman SNI 19-7030-2004 tentang Spesifikasi Kompos dari Sampah Organik.

\section{METODE PENELITIAN}

Metode penelitian ini menggunakan desain semi quasi eksperimental dengan kelompok kontrol dan kelompok perlakuan. Kelompok kontrol yaitu sampah sayuran tanpa penambahan bioaktivator. Kelompok perlakuan yaitu sampah sayuran dengan penambahan bioaktivator EM4. Penelitian ini dilaksanakan di Laboratorium Kesehatan Lingkungan PSDKU Universitas Airlangga di Banyuwangi selama bulan Februari hingga April 2019 
dengan menguji parameter suhu, kelembapan, $\mathrm{pH}$, bau, warna dan tekstur pada kompos. Pengambilan bahan sampah sayuran didapatkan dari Pasar Tradisional dan Pedagang Sayur Rumahan di Kabupaten Banyuwangi sedangkan larutan EM4 dibeli dari Dinas Pertanian Kabupaten Banyuwangi. Bahan yang digunakan pada penelitian ini adalah sampah sayuran, starter kompos jadi, sekam dan bioaktivator EM4. Alat yang digunakan dalam penelitian ini adalah keranjang takakura, tutup keranjang, alat pengaduk, pisau, talenan, kardus bekas, kain hitam, bantalan sekam, timbangan, masker, sarung tangan, soil moisture $\mathrm{pH}$ meter untuk mengukur $\mathrm{pH}$ dan kelembapan kompos serta thermohyrometer untuk mengukur suhu pengomposan.

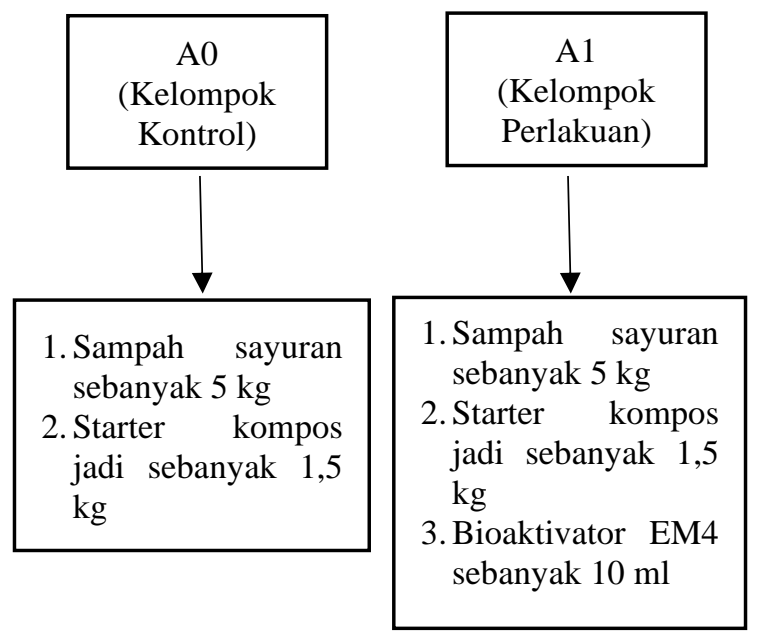

Gambar 1. Komposisi Kelompok kontrol dan kelompok perlakuan

Penelitian ini menggunakan rancangan yang terdiri dari dua kelompok yaitu kelompok kontrol yaitu pengomposan takakura tanpa penambahan bioaktivator dan kelompok perlakuan yaitu pengomposan takakura dengan penambahan bioaktivator.

Prosedur penelitian :

a.Pengomposan takakura tanpa penambahan bioaktivator EM4

Pada awalnya dilakukan pengumpulan sampah sayuran kemudian dilakukan pencacahan hingga ukuran sampah menjadi kecil-kecil dengan ukuran $1 \mathrm{~cm}$, penimbangan sampah sayuran sebanyak $5 \mathrm{~kg}$ dan penimbangan stater kompos jadi sebanyak 1,5 $\mathrm{kg}$. Setelah itu, mempersiapkan keranjang takakura terlebih dahulu kemudian disekeliling keranjang bagian dalam dilapisi dengan kardus bekas dan letakkan bantalan sekam di bagian dasar keranjang. Kemudian dilakukan pencampuran dan pengadukan sampah sayuran dengan starter kompos jadi hingga merata dan masukkan campuran tersebut ke dalam keranjang takakura. Langkah selanjutnya adalah letakkan bantalan sekam kembali di atas kompos dan ditutup dengan menggunakan kain berwarna hitam dilanjutkan dengan tutup keranjang. Pengukuran kompos dilakukan dua kali dalam seminggu sehingga menghasilkan pengukuran mulai dari hari ke-1 hingga hari ke-51 dengan cara mengukur dan mengamati suhu, $\mathrm{pH}$, kelembapan, warna, bau dan tekstur kompos. Pemanenan kompos dilakukan setelah 1,5 bulan proses pengomposan dengan cara mengambil kompos dari keranjang kemudian diayak untuk dapat dijadikan sebagai pupuk organik.

b.Pengomposan takakura dengan penambahan bioaktivator EM4

Pada awalnya dilakukan pengumpulan sampah sayuran kemudian dilakukan pencacahan hingga ukuran sampah menjadi kecil-kecil dengan ukuran $1 \mathrm{~cm}$, penimbangan sampah sayuran sebanyak $5 \mathrm{~kg}$ dan penimbangan stater kompos jadi sebanyak 1,5 $\mathrm{kg}$. Setelah itu, mempersiapkan keranjang takakura terlebih dahulu kemudian disekeliling keranjang bagian dalam dilapisi dengan kardus bekas dan letakkan bantalan sekam di bagian dasar keranjang. Kemudian dilakukan pencampuran dan pengadukan sampah sayuran dengan starter kompos jadi hingga merata dan masukkan campuran tersebut ke dalam keranjang takakura. Kemudian menambahkan bioaktivator larutan EM4 sebanyak $10 \mathrm{ml}$ dan diaduk kembali secara merata. Larutan Effective Microorganisme 4 (EM4) merupakan bioaktivator yang digunakan dalam pembuatan kompos yang dapat mempercepat proses penguraian pengomposan dan sebagai inokulan untuk meningkatkan keragaman dan populasi mikroorganisme di dalam tanah dan tanaman yang nantinya dapat meningkatkan pertumbuhan, kesehatan, kualitas dan kuantitas hasil tanaman. Langkah selanjutnya adalah letakkan bantalan sekam kembali di atas kompos dan ditutup dengan menggunakan kain berwarna hitam dilanjutkan dengan tutup keranjang. Pengukuran kompos dilakukan dua kali dalam seminggu sehingga menghasilkan pengukuran mulai dari hari ke-1 hingga hari ke-51 dengan cara mengukur dan mengamati 
suhu, $\mathrm{pH}$, kelembapan, warna, bau dan tekstur kompos. Pemanenan kompos dilakukan setelah 1,5 bulan proses pengomposan dengan cara mengambil kompos dari keranjang kemudian diayak untuk dapat dijadikan sebagai pupuk organik.

Selain pengukuran, kedua kelompok pengomposan dilakukan pengadukan dan pembalikan kompos setiap 2 kali dalam seminggu pada waktu pengukuran, penambahan sampah sayuran pada hari ke-16 sebanyak $5 \mathrm{~kg}$ dan hari ke-30 sebanyak $5 \mathrm{~kg}$, penambahan sekam sebanyak $0,5 \mathrm{~kg}$ pada hari ke-17 dan penjemuran kompos sehingga kompos menjadi matang pada hari ke-51.

Penelitian ini dilakukan melalui 3 tahapan yaitu (1) tahapan uji pengumpulan sampah organik (sampah sayuran) yang diambil dari sumbernya yaitu dari beberapa pasar tradisional dan rumah pedagang, (2) tahapan eksperimen dan pelaksanaan yaitu dilakukannya persiapan bahan baku, pencacahan sampah, persiapan alat, dan bioaktivator yang digunakan larutan EM4 serta perlakuan pengomposan dan pengukuran parameter fisik kompos selama proses pengomposan berlangsung dan (3) tahapan analisis hasil penguraian selama pengomposan berlangsung sampai selesai pengomposan yang dilakukan mulai pengukuran pada hari ke-1 hingga hari ke-51 (selama 1,5 bulan) yang meliputi pengukuran suhu, kelembapan, $\mathrm{pH}$, warna, bau dan tekstur kompos.

\section{HASIL DAN PEMBAHASAN}

Berdasarkan hasil pengukuran pada dua kelompok pembuatan kompos metode takakura yaitu kelompok kontrol dan kelompok perlakuan menunjukkan bahwa parameter kompos (suhu, kelembapan, pH, warna, bau dan tekstur) sesuai dengan pedoman yang telah ditetapkan pada SNI 19-7030-2004 tentang Spesifikasi Kompos dari Sampah Organik.

\section{Analisis Suhu Kompos}

Suhu sangat berpengaruh terhadap proses pengomposan dikarenakan berkaitan dengan jenis mikroorganisme yang terlibat didalamnya. Suhu pada proses pembuatan kompos dari sampah sayuran tanpa penambahan bioaktivator (kelompok kontrol) dan dengan penambahan biaktivator EM4 (kelompok perlakuan) selalu berubah-ubah sepanjang pengukuran, dimana suhu pada kelompok kontrol antara $29^{\circ} \mathrm{C}$ sampai $39^{\circ} \mathrm{C}$ sedangkan suhu pada kelompok perlakuan antara $28^{\circ} \mathrm{C}$ sampai $40^{\circ} \mathrm{C}$.

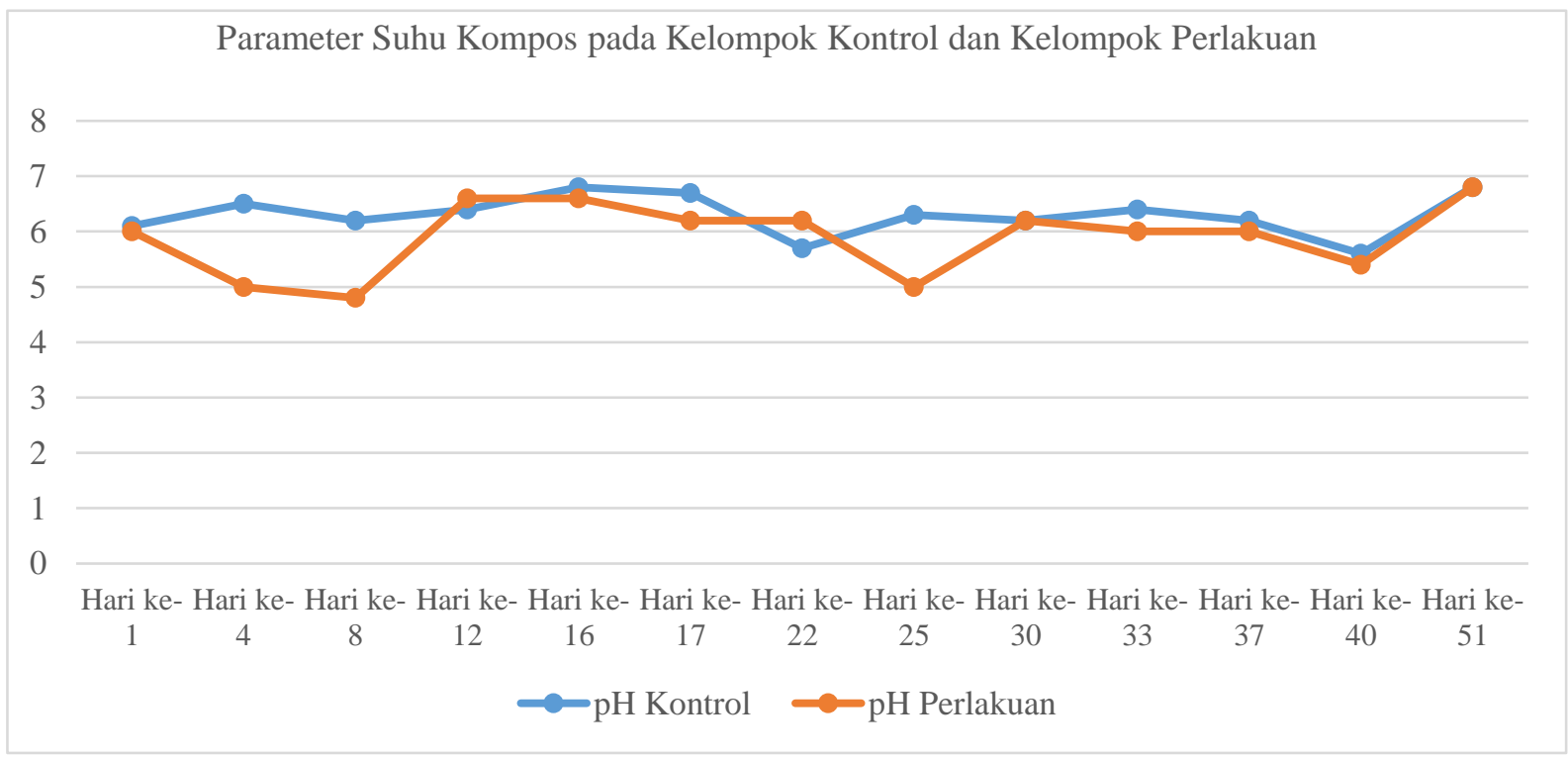

Gambar 2. Hasil pengukuran parameter suhu kompos pada kelompok kontrol dan kelompok perlakuan

Suhu pada hari ke-1 kelompok kontrol adalah $30^{\circ} \mathrm{C}$. Kemudian suhu mengalami peningkatan pada hari ke-2 sebesar $39^{\circ} \mathrm{C}$. Keadaan ini menandakan proses penguraian sudah mulai berjalan karena sejumlah bakteri merubah sampah organik menjadi bahan-bahan yang lebih sederhana yang mudah diserap oleh tanaman, dimana semakin tinggi suhu akan semakin banyak konsumsi oksigen dan semakin mempercepat proses penguraian sampah. Selanjutnya pada pengukuran berikutnya suhu menurun dikarenakan bahan organik yang diuraikan di dalam kompos sudah mulai berkurang dan mulai menyusut. Berdasarkan 
teori dari penelitian (Subekti, A, t.t.) tentang Studi Pemanfaatan Sampah Organik menjadi Kompos mengguakan Variasi Dosis Bioaktivator (PROMI dan MOL Larutan Gula) disebutkan bahwa kisaran temperatur yang menunjukkan aktivitas pengomposan yang baik berada pada suhu $30-60^{\circ} \mathrm{C}$. Pada hari ke-51 suhu kompos kelompok kontrol menjadi $29{ }^{\circ} \mathrm{C}$ dikarenakan adanya proses pembalikan untuk mengontrol suhu agar suhu sesuai dengan pedoman SNI 19-7030-2004.

Begitu juga suhu pada hari ke-1 kelompok perlakuan adalah $30^{\circ} \mathrm{C}$. Kemudian suhu mengalami peningkatan pada hari ke-4 menjadi $35^{\circ} \mathrm{C}$. Kemudian pada hari ke-33 menuju hari ke-37 terjadi penurunan yang signifikan dari suhu $40^{\circ} \mathrm{C}$ menjadi $29^{\circ} \mathrm{C}$, dikarenakan bahan organik yang terdapat di dalam kompos sudah mulai berkurang dan mulai menyusut (Wellang et. al, 2015). Mikroorganisme yang terdapat dalam larutan EM4 diketahui mempunyai suhu pertumbuhan optimal yaitu pada kisaran $40^{\circ} \mathrm{C}$. Berdasarkan penelitian sebelumnya mengenai Pengolahan Sampah di TPA Putri Cempo Mojosongo Surakarta menyebutkan bahwa suhu pada hasil dengan penambahan EM4 tidak panas $<40^{\circ} \mathrm{C}$, sehingga pada hasil suhu pembuatan kompos dengan penambahan EM4 mengindikasikan mikroorganisme pengurai bekerja dengan baik. Pada hari ke-51 suhu kompos kelompok perlakuan menjadi $30^{\circ} \mathrm{C}$ dan suhu sesuai dengan pedoman SNI 19-7030-2004. Pembuatan kompos sampah sayuran dengan metode takakura didapatkan parameter suhu kelompok perlakuan sebesar $30^{\circ} \mathrm{C}$ lebih tinggi dibanding dengan kelompok kontrol sebesar $29^{\circ} \mathrm{C}$.

\section{Analisis Kelembapan Kompos}

Kelembapan kompos pada kelompok kontrol cenderung tinggi mulai awal pengukuran dari $50 \%$ menjadi $>80 \%$ atau sangat lembab kemudian mengalami penurunan dan kembali ke kondisi normal atau stabil.



Gambar 3. Hasil pengukuran parameter kelembapan kompos pada kelompok kontrol dan kelompok perlakuan

Kelembapan pada hari ke-1 proses pengomposan masih normal yaitu $50 \%$. Kemudian kelembapan menjadi $>80 \%$ atau sangat lembab pada hari ke-4. Hal tersebut dikarenakan adanya proses pembalikan yang baru sekali dilakukan sehingga kadar oksigen tidak mencukupi. Apabila kadar oksigen tidak mencukupi atau menurun maka kandungan air menjadi meningkat dan menyebabkan sangat lembab. Pada hari ke-51, kelembapan kompos kembali normal menjadi $45 \%$ dan kelembapan tersebut sesuai dengan pedoman SNI 19-70302004.
Sedangkan pada pengomposan kelompok perlakuan kelembapan pada hari ke-1 dan hari ke-4 sebesar $>80 \%$ atau sangat lembab. Keadaan ini dikarenakan sayuran yang digunakan adalah sampah sayuran campuran. Kemudian mengalami penurunan sinifikan pada hari ke-4 menuju hari ke-12 menjadi 45\%, dikarenakan faktor lingkungan yang pada sebelum h-1 dilakukannya pengukuran tersebut terjadi hujan deras sehingga mempengaruhi kelembapannya. Selanjutnya mengalami peningkatan yang signifikan pada hari ke-12 menuju hari ke-16 dari $45 \%$ menjadi $>80 \%$ atau 
sangat lembab dikarenakan faktor penambahan sampah sayuran. Kelembaban pada kompos akan mempengaruhi mikroorganisme yang terlibat dalam pengomposan (Yenie, 2008). Apabila kelembaban kompos terlalu tinggi maka proses penguraian akan terhambat. Hal ini dikarenakan kandungan air akan menutupi rongga udara di dalam tumpukan sehingga oksigen menjadi berkurang yang akan menyebabkan mikroorganisme aerobik mati dan digantikan oleh mikroorganisme anaerobik. Pada hari ke-51, kelembapan kompos kembali normal menjadi $50 \%$ dan kelembapan tersebut sesuai dengan pedoman SNI 19-7030-2004. Pembuatan kompos sampah sayuran dengan metode takakura didapatkan parameter kelembapan kelompok perlakuan sebesar 50\% lebih tinggi dibanding dengan kelompok kontrol sebesar $45 \%$.

\section{Analisis pH Kompos}

Pada proses pembuatan kompos kelompok kontrol dan kelompok perlakuan pada pengukuran pertama memiliki $\mathrm{pH}$ yang rendah atau cenderung bersifat asam.

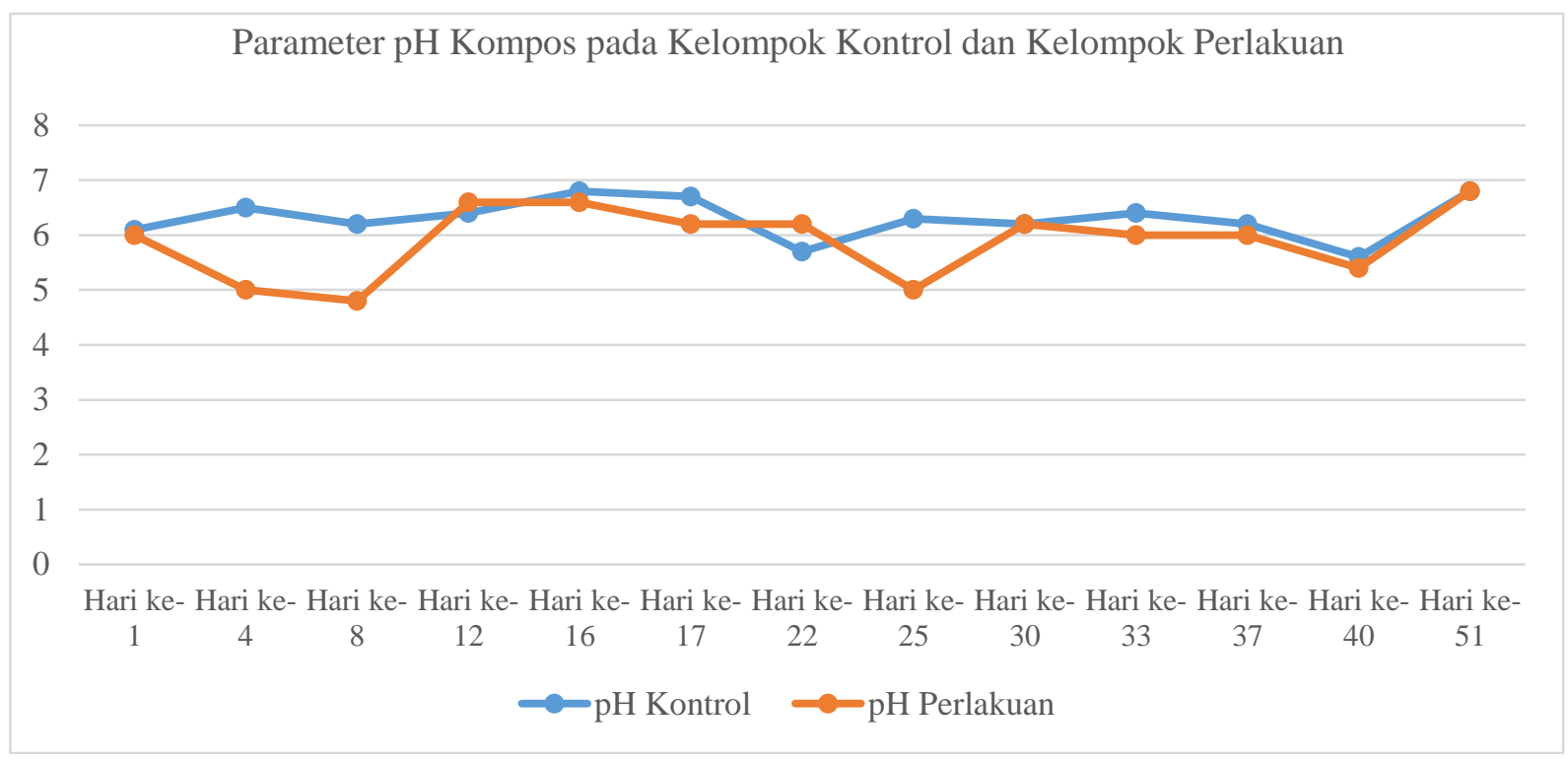

Gambar 3. Hasil pengukuran parameter pH kompos pada kelompok kontrol dan kelompok perlakuan

Berdasarkan Gambar 3, dapat dilihat bahwa $\mathrm{pH}$ kompos rata-rata pada proses pengomposan kelompok kontrol terjadi perubahan yang tidak signifikan. Hasil $\mathrm{pH}$ pada kelompok kontrol didapatkan relatif rendah atau bersifat asam pada keseluruhan pengukuran dikarenakan terjadi proses pembentukan asamasam organik dan menyebabkan pertumbuhan jamur pada kompos (Nurdini et. al, 2016). pH kompos pada awal pengukuran sebesar 6,1 hingga pada hari ke-51 didapatkan hasil sebesar 6,8 . Hal tersebut sudah sesuai dengan SNI 197030-2004 yaitu nilai $\mathrm{pH}$ sebesar 6,8 - 7,4.

Sedangkan $\mathrm{pH}$ pada pengomposan kelompok perlakuan pada awal pengukuran memiliki $\mathrm{pH}$ rendah atau bersifat asam yaitu sebesar 6,0 karena sejumlah bakteri merubah bahan organik menjadi asam organik kemudian pH naik karena sejumlah bakteri memanfaatkan kembali asam organiknya sebagai sumber energi dan sampah yang digunakan adalah sampah sisa sayuran yang disebabkan kondisi cuaca yang kurang baik karena pada waktu sebelum h-1 pengukuran terjadi hujan. Kemudian $\mathrm{pH}$ menurun hingga kembali netral. Selanjutnya hasil hari ke-51 mencapai nilai $\mathrm{pH}$ kompos sebesar 6,8 sehingga telah memenuhi standar SNI 14-7030-2004 yaitu nilai pH 6,87,4 . Pembuatan kompos sampah sayuran dengan metode takakura didapatkan parameter pH kelompok kontrol dan kelompok perlakuan sama yaitu sebesar 6,8 .

\section{Analisis Warna Kompos}

Pada warna kompos kelompok kontrol dan kelompok perlakuan pada awal pembuatan kompos berwarna hijau kehitaman dan semakin lama akan menyerupai warna tanah berwarna kehitaman. Warna pada proses pengomposan dari sampah sayuran tanpa dan dengan penambahan EM4 sudah sesuai dengan standar yang sudah ditetapkan yaitu SNI 19-7030-2004 yaitu kehitaman. Hal tersebut sejalan dengan penelitian (Zuhrufah et. al, 2015), didapatkan 
bahwa pembuatan pupuk organik dengan metode takakura menggunakan penambahan bioaktivator EM4 didapatkan hasil pupuk berwarna sangat hitam menyerupai tanah, berbau tanah dan memiliki tekstur remah serta halus. Sedangkan pupuk organik takakura tanpa penambahan bioaktivator EM4 didapatkan hasil berwarna lebih coklat, berbau seperti tanah dan memiliki tekstur remah namun lebih kasar.

\section{Analisis Warna Kompos}

Pada warna kompos kelompok kontrol dan kelompok perlakuan pada awal pembuatan kompos berwarna hijau kehitaman dan semakin lama akan menyerupai warna tanah berwarna kehitaman. Warna pada proses pengomposan dari sampah sayuran tanpa dan dengan penambahan EM4 sudah sesuai dengan standar yang sudah ditetapkan yaitu SNI 19-7030-2004 yaitu kehitaman. Hal tersebut sejalan dengan penelitian (Zuhrufah et. al, 2015), didapatkan bahwa pembuatan pupuk organik dengan metode takakura menggunakan penambahan bioaktivator EM4 didapatkan hasil pupuk berwarna sangat hitam menyerupai tanah, berbau tanah dan memiliki tekstur remah serta halus. Sedangkan pupuk organik takakura tanpa penambahan bioaktivator EM4 didapatkan hasil berwarna lebih coklat, berbau seperti tanah dan memiliki tekstur remah namun lebih kasar.

Tabel 1. Perbandingan hasil pengukuran parameter kualitas fisik kompos (warna, bau dan tekstur) sampah sayuran pada kelompok kontrol dan kelompok perlakuan berdasarkan SNI 19-7030-2004

\begin{tabular}{|c|c|c|c|c|c|c|}
\hline \multirow{2}{*}{$\begin{array}{l}\text { Hari } \\
\text { ke- }\end{array}$} & \multicolumn{3}{|c|}{$\begin{array}{c}\text { Kelompok Kontrol (Tanpa Penambahan } \\
\text { Bioaktivator) }\end{array}$} & \multicolumn{3}{|c|}{$\begin{array}{c}\text { Kelompok Perlakuan (Dengan Penambahan } \\
\text { Bioaktivator EM4) }\end{array}$} \\
\hline & Warna & Bau & Tekstur & Warna & Bau & Tekstur \\
\hline 1. & $\begin{array}{c}\text { Hijau } \\
\text { kehitaman }\end{array}$ & $\begin{array}{l}\text { Berbau } \\
\text { sampah } \\
\text { sayuran }\end{array}$ & $\begin{array}{l}\text { Seperti tekstur } \\
\text { tanah dan kasar }\end{array}$ & $\begin{array}{c}\text { Hijau } \\
\text { kehitaman }\end{array}$ & $\begin{array}{l}\text { Berbau } \\
\text { sampah } \\
\text { sayuran }\end{array}$ & $\begin{array}{c}\text { Kasar dan masih } \\
\text { berbentuk bahan } \\
\text { dasar }\end{array}$ \\
\hline 2. & $\begin{array}{c}\text { Hitam } \\
\text { kehijauan tetapi } \\
\text { hitamnya lebih } \\
\text { pekat }\end{array}$ & Berbau tanah & $\begin{array}{l}\text { Seperti tekstur } \\
\text { tanah dan kasar }\end{array}$ & $\begin{array}{c}\text { Hitam } \\
\text { kehijauan }\end{array}$ & Berbau tanah & $\begin{array}{l}\text { Seperti tekstur } \\
\text { tanah dan kasar }\end{array}$ \\
\hline 3. & Kehitaman & Berbau tanah & $\begin{array}{l}\text { Seperti tekstur } \\
\text { tanah dan } \\
\text { sedikit halus } \\
\end{array}$ & $\begin{array}{l}\text { Hitam } \\
\text { kecoklatan }\end{array}$ & Berbau tanah & $\begin{array}{l}\text { Seperti tekstur } \\
\text { tanah dan kasar }\end{array}$ \\
\hline 4. & Kehitaman & Berbau tanah & $\begin{array}{l}\text { Seperti tekstur } \\
\text { tanah dan } \\
\text { sedikit halus }\end{array}$ & $\begin{array}{c}\text { Hitam } \\
\text { kecoklatan }\end{array}$ & Berbau tanah & $\begin{array}{l}\text { Seperti tekstur } \\
\text { tanah dan kasar }\end{array}$ \\
\hline 5. & $\begin{array}{c}\text { Hitam } \\
\text { kehijauan }\end{array}$ & $\begin{array}{c}\text { Berbau } \\
\text { sayuran dan } \\
\text { sedikit tanah } \\
\end{array}$ & $\begin{array}{c}\text { Tekstur kasar } \\
\text { seperti sampah } \\
\text { sayuran } \\
\end{array}$ & $\begin{array}{c}\text { Hitam } \\
\text { kecoklatan }\end{array}$ & Berbau tanah & $\begin{array}{l}\text { Seperti tekstur } \\
\text { tanah dan kasar }\end{array}$ \\
\hline 6. & $\begin{array}{l}\text { Hijau, hitam } \\
\text { dan coklat }\end{array}$ & $\begin{array}{c}\text { Berbau } \\
\text { sampah } \\
\text { sayuran dan } \\
\text { sekam }\end{array}$ & $\begin{array}{l}\text { Seperti tekstur } \\
\text { tanah dan kasar }\end{array}$ & $\begin{array}{c}\text { Hitam } \\
\text { kehijauan }\end{array}$ & $\begin{array}{c}\text { Berbau tanah } \\
\text { dan sayuran }\end{array}$ & $\begin{array}{l}\text { Seperti tekstur } \\
\text { tanah dan kasar }\end{array}$ \\
\hline 7. & Kehitaman & Berbau tanah & $\begin{array}{c}\text { Seperti tekstur } \\
\text { tanah, kasar dan } \\
\text { basah }\end{array}$ & $\begin{array}{c}\text { Hitam } \\
\text { kecoklatan }\end{array}$ & $\begin{array}{l}\text { Berbau tanah } \\
\text { dan sedikit } \\
\text { sayuran }\end{array}$ & $\begin{array}{l}\text { Seperti tekstur } \\
\text { tanah dan kasar }\end{array}$ \\
\hline 8. & Kehiataman & Berbau tanah & $\begin{array}{l}\text { Seperti tekstur } \\
\text { tanah dan kasar }\end{array}$ & $\begin{array}{c}\text { Hitam } \\
\text { kecoklatan }\end{array}$ & Berbau tanah & $\begin{array}{l}\text { Seperti tekstur } \\
\text { tanah dan kasar }\end{array}$ \\
\hline 9. & $\begin{array}{c}\text { Hitam } \\
\text { kehiajuan }\end{array}$ & $\begin{array}{c}\text { Berbau } \\
\text { sayuran dan } \\
\text { sedi kit tanah } \\
\end{array}$ & $\begin{array}{c}\text { Tekstur kasar } \\
\text { seperti sampah } \\
\text { sayuran }\end{array}$ & $\begin{array}{c}\text { Hitam } \\
\text { kecoklatan }\end{array}$ & Berbau tanah & $\begin{array}{l}\text { Seperti tekstur } \\
\text { tanah dan kasar }\end{array}$ \\
\hline 10 & $\begin{array}{c}\text { Dominan } \\
\text { kehitaman } \\
\text { dengan sedikit } \\
\text { hijau } \\
\end{array}$ & $\begin{array}{c}\text { Berbau tanah } \\
\text { dan sayuran }\end{array}$ & $\begin{array}{l}\text { Seperti tekstur } \\
\text { tanah dan kasar }\end{array}$ & $\begin{array}{c}\text { Hitam } \\
\text { kecoklatan }\end{array}$ & Berbau tanah & $\begin{array}{l}\text { Seperti tekstur } \\
\text { tanah dan kasar }\end{array}$ \\
\hline 11. & Kehitaman & Berbau tanah & $\begin{array}{l}\text { Seperti tekstur } \\
\text { tanah dan kasar }\end{array}$ & $\begin{array}{c}\text { Hitam } \\
\text { kecoklatan }\end{array}$ & Berbau tanah & $\begin{array}{l}\text { Seperti tekstur } \\
\text { tanah dan kasar }\end{array}$ \\
\hline 12. & Kehitaman & Berbau tanah & $\begin{array}{l}\text { Seperti tekstur } \\
\text { tanah dan kasar }\end{array}$ & Kehitaman & Berbau tanah & $\begin{array}{l}\text { Seperti tekstur } \\
\text { tanah dan kasar }\end{array}$ \\
\hline 13. & Kehitaman & Berbau tanah & $\begin{array}{l}\text { Seperti tekstur } \\
\text { tanah dan kasar }\end{array}$ & Kehitaman & Berbau tanah & $\begin{array}{l}\text { Seperti tekstur } \\
\text { tanah dan kasar }\end{array}$ \\
\hline
\end{tabular}




\section{Analisis Bau Kompos}

Pada bau kompos kelompok kontrol dan kelompok perlakuan pada awal pembuatan kompos berbau sampah sayuran dan semakin lama akan berbau tanah. Bau pada proses pengomposan kelompok kontrol dan kelompok perlakuan sudah sesuai dengan standar yang sudah ditetapkan yaitu SNI 19-7030-2004.

\section{Analisis Tekstur Kompos}

Pada tekstur kompos sampah sayuran tanpa atau dengan penambahan EM4 pada awal pembuatan kompos memiliki tekstur sayuran dan semakin lama akan memiliki seperti terkstur kasar dan menyerupai tanah. Tekstur pada proses pengomposan dari sampah sayuran tanpa atau dengan penambahan EM4 sudah sesuai dengan standar yang sudah ditetapkan yaitu SNI 19-7030-2004.

Pada pembuatan kompos dari sampah sayuran tanpa penambahan bioaktivator (kelompok kontrol) merupakan pengomposan dengan cara alami tanpa tambahan bioaktivator untuk mempercepat pengomposan. Proses penguraian sampah sayuran pada kompos ini terjadi lebih lama yaitu selama 25 hari. Sampah sayuran yang digunakan adalah sayuran kangkung. Hal tersebut sejalan dengan hasil penelitian sebelumnya mengenai Studi Optimasi Kematangan Kompos dari Sampah Organik dengan Penambahan Bioaktivator Limbah Rumen dan Air Lindi menyatakan bahwa pada proses pengomposan alami tanpa penambahan bioaktivator akan berjalan lebih lama dibandingkan dengan menggunakan penambahan bioktivator karena mikroorganisme yang bekerja secara alami (Dewilda dan Apris, 2016).

Pada pembuatan kompos sampah sayuran dengan penambahan bioaktivator EM4 dapat mempercepat proses penguraian sampah organik dari sampah sayuran, yang mana waktu pengomposan dengan penggunaan EM4 dapat dipercepat yaitu hanya membutuhknan waktu berkisar antara 3-5 hari. Waktu proses pengomposan sampah sayuran terjadi selama 12 hari. Sampah sayuran yang digunakan adalah sayuran campuran. Hal ini akan berpengaruh pada suhu kompos. Penelitian ini tidak sejalan dengan hasil penelitian sebelumnya tentang Optimasi Kondisi Proses Pembuatan Kompos Organik dengan Cara Fermentasi menggunakan EM4 menyatakan bahwa semakin besar konsentrasi EM4 yaitu konsentrasi 0,5\% maka semakin cepat waktu pengomposan yaitu selama 4 hari (Yuniwati et. al, 2012).

Kelemahan dari penelitian ini adalah hanya mengukur pada parameter fisik kompos dan variasi bahan bakunya sedikit, tidak ada variasi penambahan biaoktivator lain guna mempercepat proses pengomposan dan tidak dilakukannya penimbangan berat kompos pada setiap dilakukannya pengukuran. Manfaat dari penelitian ini untuk mengetahui cara pengolahan sampah sayuran melalui pembuatan kompos dengan penambahan atau tanpa penambahan bioaktivator EM4 yang sesuai dengan syarat yang ditetapkan. Selain itu, mengetahui perbadingan pada kedua kelompok pembuatan kompos takakura yaitu antara pengomposan sampah sayuran tanpa penambahan bioaktivator (kontrol) dan dengan penambahan bioaktivator EM4 (perlakuan).

\section{KESIMPULAN DAN SARAN}

Berdasarkan hasil analisis dan pembahasan, dapat ditarik kesimpulan yaitu proses pembuatan kompos dengan metode takakura dilakukan pada dua kelompok yaitu kelompok kontrol pembuatan kompos sampah sayuran tanpa penambahan bioaktivator dan kelompok perlakuan pembuatan kompos sampah sayuran dengan penambahan bioaktivator EM4. Pada pembuatan kompos dengan sampah sayuran metode takakura didapatkan parameter suhu kelompok perlakuan lebih tinggi sebesar $30^{\circ} \mathrm{C}$ dibanding dengan kelompok control sebesar $29^{\circ} \mathrm{C}, \mathrm{pH}$ kedua kelompok sama sebesar 6,8, kelembapan kelompok perlakuan sebesar 50\% lebih tinggi atau lembab dibandingkan dengan kelompok kontrol sebesar $45 \%$ serta warna, bau dan tekstur kedua kelompok sama. Pada dua kelompok tersebut sudah memenuhi standar SNI-19-7030-2004 meliputi parameter suhu, kelembapan, pH, warna, bau dan tekstur kompos sehingga kompos sudah dapat digunakan sebagai pupuk organik. Dari kedua cara pembuatan kompos didapatkan bahwa waktu pengomposan sampah sayuran kangkung tanpa bioaktivator yaitu selama 25 hari dan waktu penguraian kompos sampah sayuran campuran dengan bioaktivator EM4 waktu penguraian yaitu selama 12 hari. Perlu memperhatikan dalam hal manajemen waktu dalam pembuatan kompos dengan metode takakura dan penyimpanan kompos yang harus memperhatikan lokasi yang berkaitan dengan 
faktor lingkungan setempat karena akan mempengaruhi kondisi kompos.

Diharapkan penelitian selanjutnya perlu dilakukan mengenai penggunaan bahan baku yang lebih variasi dan penambahan bioaktivator lain sehingga dapat mempercepat pengomposan dan mengurangi penumpukan sampah terutama sampah sayuran serta perlu dilakukan penelitian lebih lanjut mengenai pengukuran parameter lain seperti penyusutan, kadar air, rasio $\mathrm{C} / \mathrm{N}$, karbon $(\mathrm{C})$, nitrogen $(\mathrm{N})$, kalium $\left(\mathrm{K}_{2} \mathrm{O}\right)$ dan phosphor $\left(\mathrm{P}_{2} \mathrm{O}_{5}\right)$ dari awal pengomposan sampai hasil akhir kompos untuk memenuhi kriteria kompos matang.

\section{DAFTAR RUJUKAN}

1] Badan Standardisasi Nasional. (2004) Standar Nasional Indonesia 19-7030-2004 Spesifikasi Limbah Domestik.

2] Dewilda, Y., \& Apris, I. (2016) Studi Optimasi Kematangan Kompos Dari Sampah Organik Dengan Penambahan Bioaktivator Limbah Rumen Dan Air Lindi. Seminar Nasional Sains dan Teknologi Lingkungan, 6.

3] Ekawandani, N. (2018) Pengomposan Sampah Organik (Kubis dan Kulit Pisang) Dengan Menggunakan EM4 [Preprint]. https://doi.org/10.31227/osf.io/3gt26

4] Kurniati, S. (2013) Pembuatan Kompos Skala Rumah Tangga Sebagai Salah Satu Upaya Penanganan Masalah Sampah Di Kota Mataram. Media Bina Ilmiah, 7.

5] Nisandi. (2007) Pengolahan Dan Pemanfaatan Sampah Organik Menjadi
Briket Arang Dan Asap Cair. Seminar Nasional Teknologi 2007.

6] Nurdini, L., Amanah, R. D., \& Utami, A. N. (2016) Pengolahan Limbah Sayur Kol menjadi Pupuk Kompos dengan Metode Takakura. Prosiding Seminar Nasional Teknik Kimia "Kejuangan," 6.

7] Peraturan Daerah Banyuwangi. (2013) Peraturan Daerah Kabupaten Banyuwangi Nomor 9 Tahun 2013 Tentang Pengelolaan Sampah Rumah Tangga dan Sejenis Sampah Rumah Tangga.

8] Wellang, R. M., Rahim, I. R., \& Hatta, M. P. (2015) Studi Kelayakan Kompos Menggunakan Variasi Bioaktivator (EM4 dan ragi). 19.

9] Yenie, E. (2008) Kelembapan Bahan Dan Suhu Kompos Sebagai Parameter Yang Mempengaruhi Proses Pengomposan Pada Unit Pengomposan Rumbai. Jurnal Sains dan Teknologi, 7, 4.

10] Yuniwati, M., Iskarima, F., \& Padulemba, A. (2012) Optimasi Kondisi Proses Pembuatan Kompos Dari Sampah Organik Dengan Cara Fermentasi Menggunakan EM4. Jurnal Teknologi, 5.

11] Zuhrufah, Izzati, M., \& Haryanti, S. (2015) Pengaruh Pemupukan Organik Takakura Dengan Penambahan EM4 Terhadap Pertumbuhan dan Produksi Tanaman Kacang Hijau (Phaeseolus radiatus L.). Jurnal Biologi, 4. 